\title{
Integrating rockfall risk assessment and countermeasure design by 3D modelling techniques
}

\author{
F. Agliardi, G. B. Crosta, and P. Frattini \\ Dipartimento di Scienze Geologiche e Geotecnologie, Università degli Studi di Milano-Bicocca, Piazza della Scienza, 4, \\ Milano - 20126, Italy
}

Received: 27 January 2009 - Revised: 22 May 2009 - Accepted: 5 June 2009 - Published: 6 July 2009

\begin{abstract}
Rockfall risk analysis for mitigation action design requires evaluating the probability of rockfall events, the spatial probability and intensity of impacts on structures, their vulnerability, and the related expected costs for different scenarios. These tasks were integrated in a quantitative risk assessment procedure supported by 3D rockfall numerical modelling performed by the original code HY-STONE. The case study of Fiumelatte (Varenna, Italy), where a large rockfall in November 2004 resulted in 2 casualties, destruction of several buildings and damage to transportation corridors, is discussed. The numerical model was calibrated by a back analysis of the 2004 event, and then run for the whole area at risk by considering scenarios without protection ( $\mathrm{S} 0$ ), with a provisional embankment (S1), and with a series of long-term protection embankments (S2). Computed impact energy and observed damage for each building impacted in 2004 were combined to establish an empirical vulnerability function, according to which the expected degree of loss for each element at risk was computed. Finally, costs and benefits associated to different protection scenarios were estimated, in order to assess both the technical performance and the cost efficiency of different mitigation options.
\end{abstract}

\section{Introduction}

Rockfalls are widespread phenomena threatening human beings and causing significant damages to structures. Thus, rockfall protection through both structural and landplanning actions is an important issue for administrators and stakeholders in rockfall prone areas (Raetzo et al., 2002; Crosta

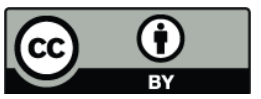

Correspondence to: F. Agliardi (federico.agliardi@unimib.it) and Agliardi, 2003; Corominas et al., 2005; Jaboyedoff et al., 2005; Straub and Schubert, 2008; Fell et al., 2008). Rockfall protection includes different tasks, namely: rockfall risk assessment for land planning and prioritization of actions; identification of mitigation options able to achieve a specified risk reduction; and evaluation of their cost efficiency to optimise budget and design. Accomplishing these tasks involves evaluating: (1) rockfall hazard over the affected area; (2) the distribution and intensity of impacts on exposed structures; (3) the vulnerability of impacted structures; (4) the expected cost of specific risk scenarios; and (5) the efficiency of mitigation options.

When dealing with natural hazards, a risk-based approach to countermeasure design should be used to account for the uncertainties related to frequency, probability of impact on exposed elements, and vulnerability (Straub and Schubert, 2008; Uzielli et al., 2008). Moreover, rockfalls are rare and strongly spatially distributed processes, characterised by complex dynamics and interaction with structures. Thus, a Quantitative Risk Analysis (QRA; Corominas et al., 2005; Fell et al., 2005) for these processes should be based on sound modelling of rockfall processes. Nevertheless, few researchers applied risk analysis to the design and evaluation of rockfall protection measures (Bunce et al., 1997; Hungr et al., 1999; Corominas et al., 2005; Straub and Schubert, 2008). Most rockfall protection studies have been aimed to susceptibility or hazard assessment (Pierson et al., 1990; Cancelli and Crosta, 1993; Mazzoccola and Sciesa, 2000; Crosta and Agliardi, 2003; Budetta, 2004; Guzzetti et al., 2004; Jaboyedoff et al., 2005; Frattini et al., 2008), while the design of structural countermeasures (e.g. barriers, embankments, rock sheds) is usually based on empirical criteria (Ritchie, 1963; Fookes and Sweeney, 1976; Nichol and Watters, 1983) or numerical modelling results (Spang, 1987; Barret and Pfeiffer, 1989; Agliardi and Crosta, 2003).

Published by Copernicus Publications on behalf of the European Geosciences Union. 


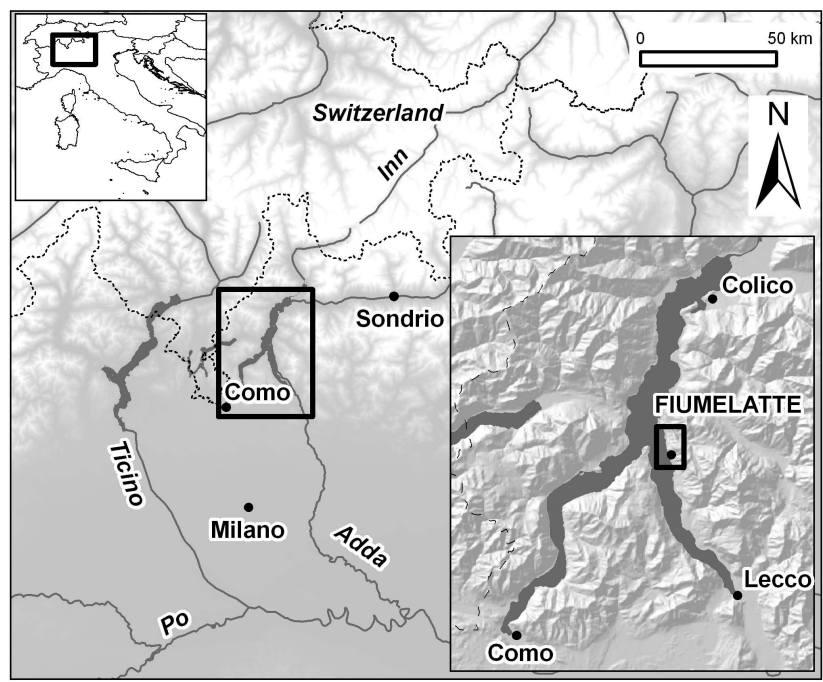

Fig. 1. Location map of the study area, south of Varenna on the eastern shore of the Lake of Como (northern Italy).

We integrated all the relevant stages of the rockfall protection process in a comprehensive approach which takes advantage of 3D mathematical modelling, providing useful insight and tools for the analysis of rockfall processes and related risks (Agliardi and Crosta, 2003; Crosta and Agliardi, 2003; Jaboyedoff et al., 2005; Frattini et al., 2008). We present the case study of Fiumelatte (Lecco, Italy; Fig. 1), where in 2004 a single rockfall event caused 2 casualties, the destruction of several buildings and the interruption of a road of regional importance, and a railway. Following the disaster, a provisional protection embankment was built, and the design of a longer and higher series of embankments was started in order to ensure long-term protection. The aim of our analysis was to verify the technical suitability and the cost-efficiency of the countermeasures through a Quantitative Risk Analysis and a cost-benefit analysis, supported by 3D mathematical modelling.

\section{The Fiumelatte rockfall event}

The Fiumelatte village is located on the eastern shore of the Lake of Como, in the municipality of Varenna (Fig. 1). The area is impended by rocky cliffs up to $300 \mathrm{~m}$ high, with slope inclination locally exceeding 70 degrees. These consist of massive or thick-bedded Middle Triassic dolostones of the Esino formation (Carnian), belonging to the upper structural unit of the Grigne massif (i.e. Northern Grigna-Coltignone Unit; Jadoul and Gaetani, 1986; Schönborn, 1992). The rock mass is cut by bedding planes gently dipping to the WNW, and NNE trending steep fractures. The intermediate part of the slope, between 270 and $500 \mathrm{~m}$ a.s.1., is covered by discontinuous, partly cemented and forested or bush-covered scree deposits with slope inclination in the range $33-38^{\circ}$.
The slope toe below $270 \mathrm{~m}$ a.s.l. is covered by colluvial soil, extensively reworked to create artificial terraces for urban development and agricultural practice. In this sector, slope inclination is in the range $20-25^{\circ}$.

This area has been recurrently affected by small rockfall events, occasionally causing fatalities (e.g. May 1987, 2 casualties in a car on SP72 road) or traffic interruptions (e.g. October 1998). This led to the construction of extensive countermeasures on the surrounding slopes, including flexible barriers and rock face cleaning/reveting. Nevertheless, no systematic record of rockfall events is available for this area.

On 13 November 2004 at 17.30 about $4000-5000 \mathrm{~m}^{3}$ of rock toppled from a rocky cliff at $650 \mathrm{~m}$ a.s.l. above Fiumelatte (Fig. 2a and b), and fragmented impacting on a rocky bench immediately downslope. A large number of blocks up to $100 \mathrm{~m}^{3}$ in volume bounced and rolled down through a channelled sector of the talus, reaching the lower part of the slope (250-270 m a.s.l., Fig. 2c). Here rockfall trajectories spread over the terraced slope, reaching the urban area below with a maximum runout distance of about $500 \mathrm{~m}$. In this sector significant lateral dispersion of rockfall trajectories occurred, with a width/length ratio of the runout area (Crosta and Agliardi, 2004) up to 0.34. Impact and rolling scours surveyed soon after the event suggest that blocks mostly bounced close to the terraced ground. Despite rockfalls are common phenomena in this area and all along the of Lake of Como, no event of this magnitude had been reported in historical times.

The rockfall damage corridor involved a $170 \mathrm{~m}$ long span of two transportation corridors (i.e. the Lecco-Colico railway track and the SP72 road) and several houses and structures, claiming two casualties (Fig. 2). Major structural damage causing total loss was suffered by a house just above the railway track and by a three-storey building where fatalities occurred (Fig. 2e), whereas other buildings, including the railway station (Fig. 2d), experienced less severe damage. The estimated cost of damage to structures reached 7000000 Euro. Impacts on the railway track caused a 8-day long traffic interruption and significant economic losses for the railway company, estimated to be about 1600000 Euro.

Soon after the event, the regional civil protection authority intervened to trim few unstable blocks on the rocky cliffs, and a provisional $180 \mathrm{~m}$ long retaining fill was built (and later raised in 2005) to face the emergency stage by protecting the damaged area. Later, a new series of three larger embankments, up to $8 \mathrm{~m}$ high and $500 \mathrm{~m}$ long, and related slope cutting was planned to ensure long-term protection to the whole exposed area (Fig. 3). 

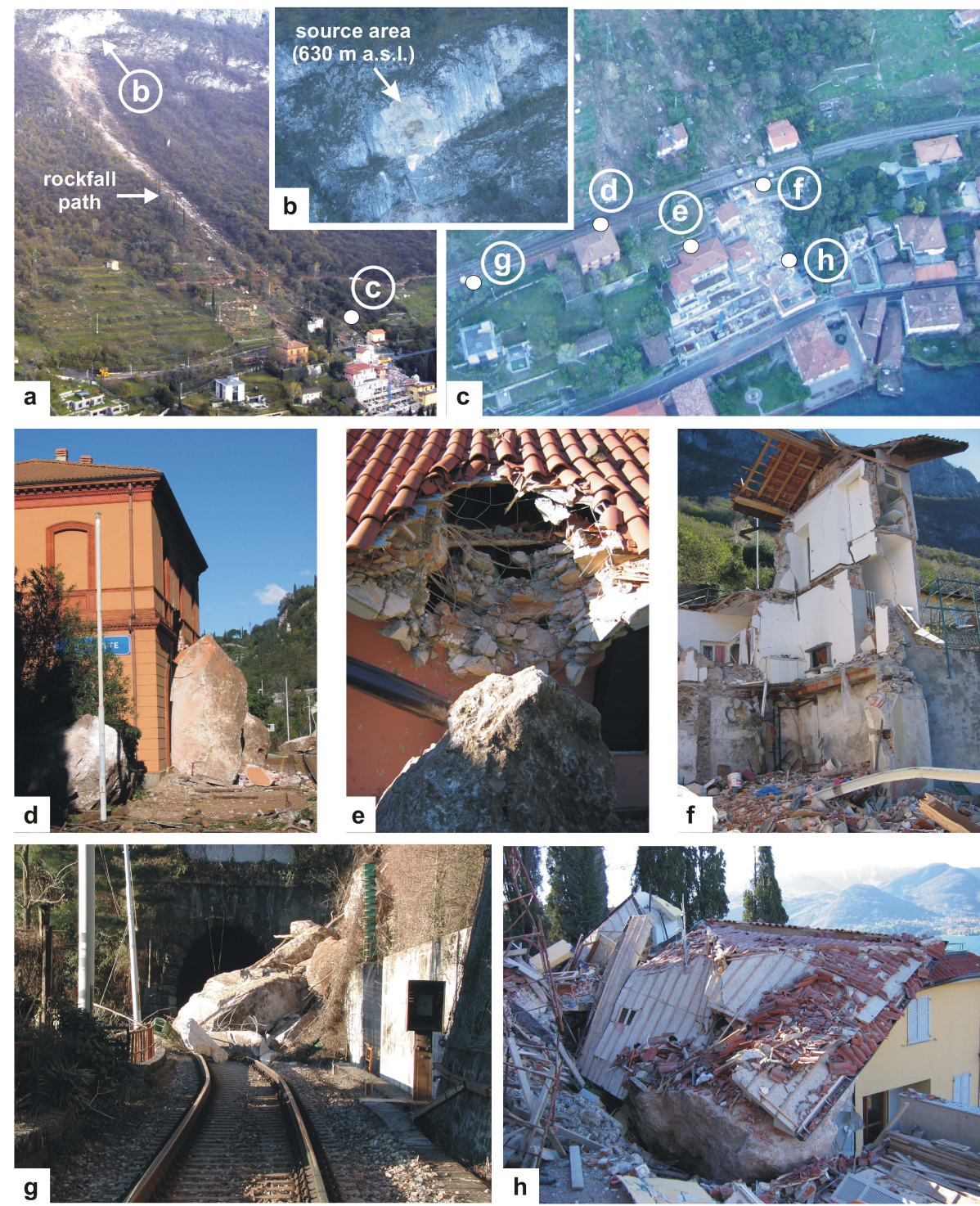

Fig. 2. The 2004 Fiumelatte rockfall event. (a) NW view of the affected area, including rockfall source and path; (b) detail of the rockfall source area; (c) aerial view of the impacted area, including the inner part of the Fiumelatte village, the Lecco-Colico railway track and the SP72 road. Numbers indicate the location of structures in d) to h). (d) railway station (n. 42 in Fig. 8), damaged by the impact of a $30 \mathrm{~m}^{3}$ block; (e) roof of building n. 46 (Fig. 8) damaged by a $8 \mathrm{~m}^{3}$ block; (f) three-storey building (A in Fig. 8) destroyed by a $96 \mathrm{~m}^{3}$ block, where two casualties also occurred; (g) damaged railway section west of the main rockfall corridor; (h) building n. 53 downslope of building A (Fig. 8), severely damaged by the same $96 \mathrm{~m}^{3}$ block.

\section{Methods}

\subsection{Risk analysis}

Rockfall risk (i.e. the annual expected cost due to the impact of rockfall events) can be defined as the simple product of three conditional probabilities, vulnerability and value, summed up for all the considered elements at risk and rockfall magnitude classes, according to the following equation (Hungr et al., 1999; Fell et al., 2005):
$R=\sum_{i=1}^{I} \sum_{j=1}^{J} P(L)_{j} \cdot P(T \mid L)_{i j} \cdot P(I \mid T)_{i} \cdot V_{i j} \cdot W_{i}$

where $P(L)_{j}$ is the probability of occurrence of a rockfall event in the magnitude (i.e. block volume) class $j$; $P(T \mid L)_{i j}$ is the probability of a block in the volume class $j$ to reach the element at risk $i$ (i.e. reach probability); $P(I \mid T)_{i}$ is the probability that a given element at risk is at the impact location at the time of impact (i.e. temporal spatial probability or exposure); $V_{i j}$ is the vulnerability (i.e. expected degree of loss) of a given element at risk $i$ to the 


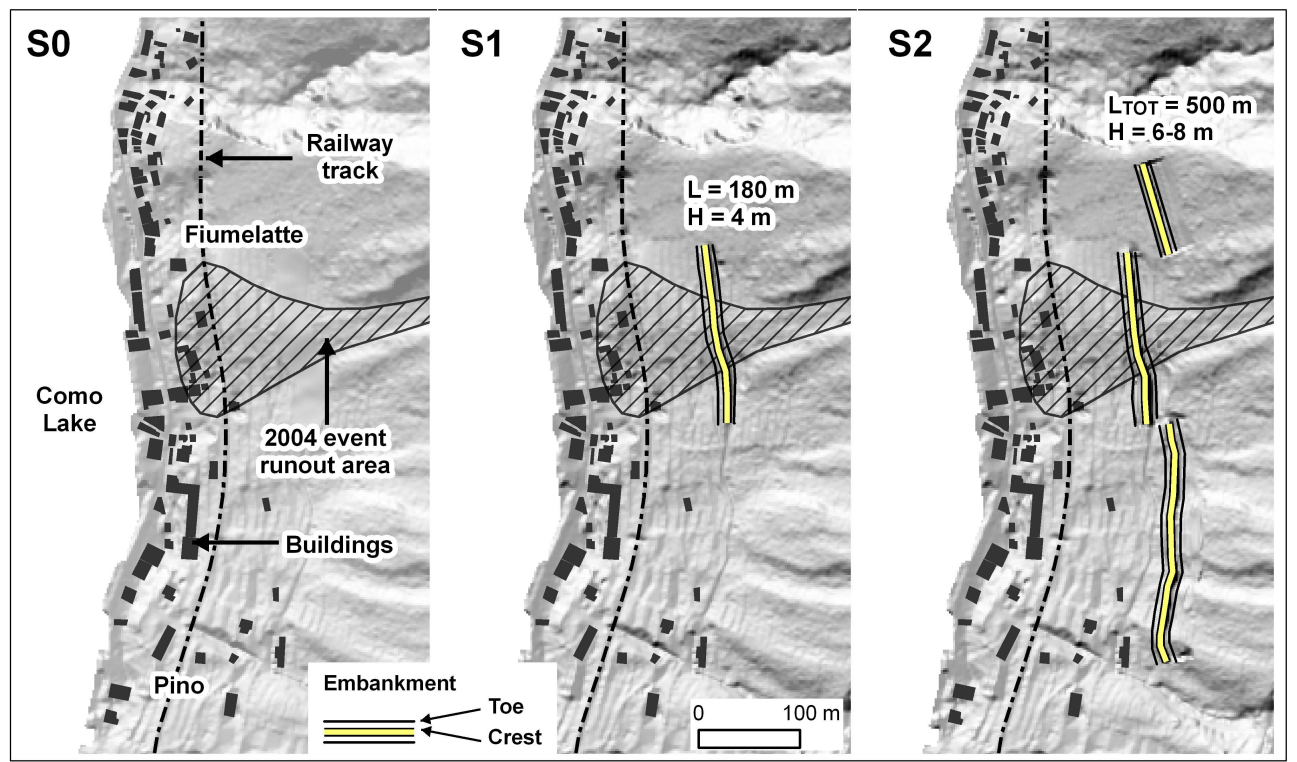

Fig. 3. Rockfall protection scenarios considered in the risk analysis. (a) reference scenario S0, corresponding to the unprotected post-2004; (b) scenario S1, protected by a provisional embankment; (c) scenario S2, with a planned set of embankments designed to ensure long-term rockfall protection of the Fiumelatte and Pino areas.

impact of a block in the magnitude class $j$; and $W_{i}$ is the economic value of the element at risk $i$.

The impact probability of rockfall in the volume class $j$ on the element at risk $i$ can be defined as:

$P(I)_{i j}=P(L)_{j} \cdot P(T \mid L)_{i j} \cdot P(I \mid T)_{i}$

thus, risk can be rewritten as:

$R=\sum_{i=1}^{I} \sum_{j=1}^{J} P(I)_{i j} \cdot V_{i j} \cdot W_{i}$

According to Hungr and Beckie (1998), rockfall probabilities can be evaluated by considering rockfall events as Bernoulli trials, i.e. simple experiments with a random binary outcome (i.e. failure or success). The probability that any impact of a rockfall in the volume class $j$ occur on the element at risk $i$ can thus be expressed as:

$P(I)_{i j}=1-\left[1-P(I \mid L)_{i j}\right]^{N_{j}}$

where $P(I \mid L)_{i j}=P(T \mid L)_{i j} \cdot P(I \mid T)_{i}$ is the probability of impact on the element at risk $i$ given that a rockfall event in the volume class $j$ occurs, and $N_{j}$ is the annual frequency of rockfall events in the volume class $j$.

For $P(I \mid L)_{i j}$ less than $10^{-3}$, and $N_{j}$ less than 100 , Eq. (4) can be approximated in practice by the following equation, being the numerical difference very small $(<5 \%$; Hungr and Beckie, 1998):

$P(I)_{i j}=N_{j} \cdot P(I \mid L)_{i j}$
Substituting in Eq. (3) we finally obtain the following expression for total rockfall risk:

$R=\sum_{i=1}^{I} \sum_{j=1}^{J} N_{j} \cdot P(T \mid L)_{i j} \cdot P(I \mid T)_{i} \cdot V_{i j} \cdot W_{i}$

\subsection{Numerical modelling}

The part of risk analysis involving the interaction between rockfalls and elements at risk (i.e. impact probability and vulnerability) was supported by high-resolution 3D numerical modelling performed through the code HY-STONE (Agliardi and Crosta, 2003; Crosta et al., 2004; Frattini et al., 2008). This code is able to simulate rockfall trajectories in $3 \mathrm{D}$ with a multi-scale stochastic approach, taking advantage of highresolution descriptions of 3D topography (e.g. LIDAR). The code incorporates a hybrid algorithm based on modifications of Pfeiffer and Bowen (1989) and Azzoni et al. (1995), allowing to model free fall, impact and rolling with different damping relationships available to simulate energy loss. Slope topography is described by a raster DEM, and all the relevant parameters are spatially distributed. The stochastic nature of rockfall processes and the variability of the relevant parameters are introduced as a function of topography and by random sampling most parameters from different probability density distributions (e.g. uniform, normal, lognormal, exponential). The model accounts for the interactions between blocks and countermeasures or structures by introducing their geometry and energy absorption capacity. An elasto-viscoplastic model (Di Prisco and Vecchiotti, 2006) 


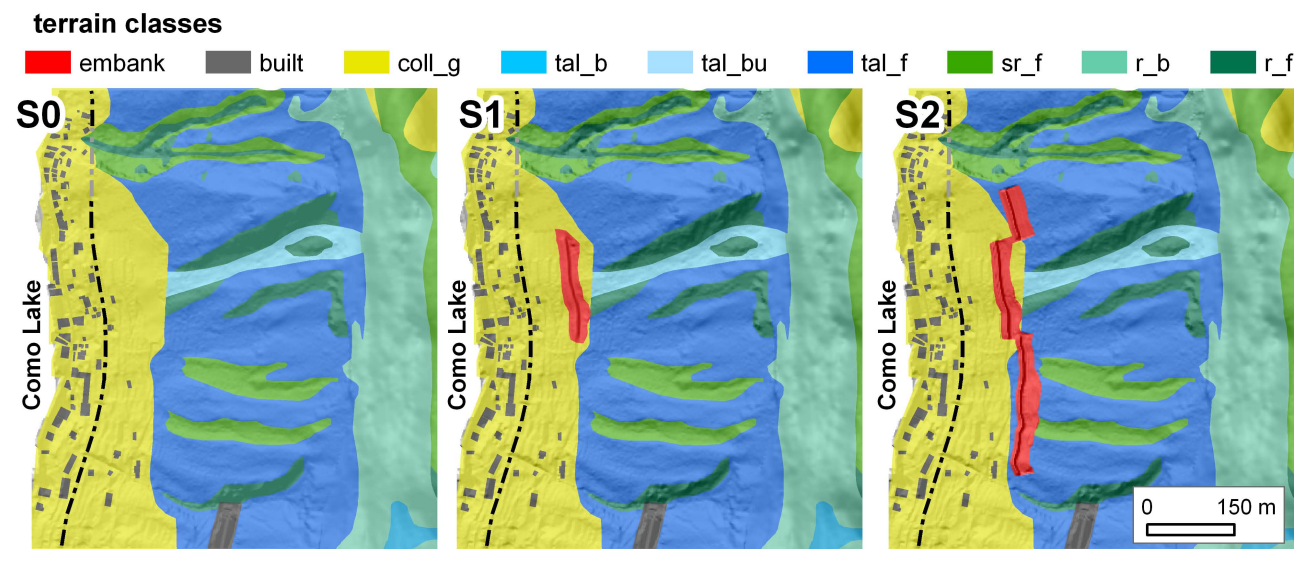

Fig. 4. Terrain classes obtained by unique condition combination of surface lithology and landuse maps, for the rockfall protection scenarios S0, S1, and S2. Calibrated model parameters assigned to each terrain class are listed in Table 1. Keys to symbols: embank =embankment fill material; built = built area; coll_g = colluvial deposit, grass covered; tal_b: talus slope, bare; tal_bu: talus slope, bush covered; tal_f: talus slope, forested; sr_f: subcropping rock, forested; r_b: outcropping rock, bare; $r_{-} f$ : outcropping rock, forested.

is also available to model impact on soft ground, whereas rockfall impacts against vegetation and fragmentation phenomena can be simulated as stochastic processes (Crosta et al., 2006) The code accepts spatially distributed input data as raster matrices, including: location of source cells, number, shape and mass of blocks, initial conditions and values of damping coefficients accounting for energy loss. Results are provided in raster and vector format, including rockfall frequency, bounce height, rotational and translational velocity and kinetic energy, as well as information about motion type, impact locations and values of impact and rebound angle at each computed point along fall paths.

\section{Quantitative risk analysis}

Quantitative risk analysis was performed for three rockfall protection scenarios, namely: a reference scenario without countermeasures (scenario S0 in Fig. 3), a scenario protected by the provisional embankment (scenario S1 in Fig. 3), and a scenario protected by the planned embankments (scenario S2 in Fig. 3).

Elements at risk considered in the analysis included the existing buildings in the Fiumelatte area and the estimated number of people inside them based on average occupancy. A building database $(I=86)$ was set up in GIS, including housing, commercial, and other buildings (e.g. railway station). For each building, several attributes relevant to risk analysis were surveyed, namely: structural type (e.g. masonry walls, reinforced concrete frame), building height, plan area, number of storeys (derived by field surveys, analysis of LIDAR topography and 1:2000 topographic maps), average commercial value per unit area (from real estate market information and reports of losses suffered in 2004), and average estimated annual people occupancy. These data allowed to estimate the value $W_{i}$ of each building. An economic value of $10^{6}$ Euro was assumed for human life using a human capital approach according to the literature (GEO, 1998; Fuchs and McAlpin, 2005; Porter et al., 2006; Jonkman, 2007). The spatial temporal probability $P(I \mid T)_{i}$ of the elements at risk (see Eq. 1) was evaluated by simple assumptions about their mobility, and set to 1 for buildings (i.e. static elements) and 0.5 for people inside buildings (conservative estimate of average daily occupancy of $12 \mathrm{~h}$ ).

In our approach, the annual frequency of rockfall events in a given volume classes $j$ (i.e. $N_{j}$ ) was evaluated using magnitude-cumulative frequency (MCF) curves according to Hungr et al. (1999) and Dussauge et al. (2003). The reach probability $P(T \mid L)_{i j}$ was derived from the results of 3D numerical modelling. The vulnerability $V_{i j}$ of the elements at risk was evaluated through a vulnerability curve, obtained by combining numerical modelling results and field data for buildings.

\subsection{Numerical model set up}

Numerical modelling of rockfalls was performed over an area of about $0.52 \mathrm{~km}^{2}$ including the whole Fiumelatte village and the above slopes, impended by rocky cliffs up to $800 \mathrm{~m}$ long. A LIDAR topography with $2 \mathrm{~m}$ spatial resolution (courtesy of Regione Lombardia) was used to describe topography, whereas rockfall source areas, surface lithology and vegetation were mapped in the field. The trajectory and maximum runout of single blocks and the related damages to structures were also mapped soon after the 2004 event.

Surface lithology and vegetation maps specifically prepared for this study have been combined in a unique condition map (Fig. 4). This allowed us to define 9 classes of slope units to be assigned initial values for the impact energy restitution $\left(e_{n}, e_{t}\right)$ and rolling friction $\left(\tan \Phi_{r}\right)$ coefficients, 


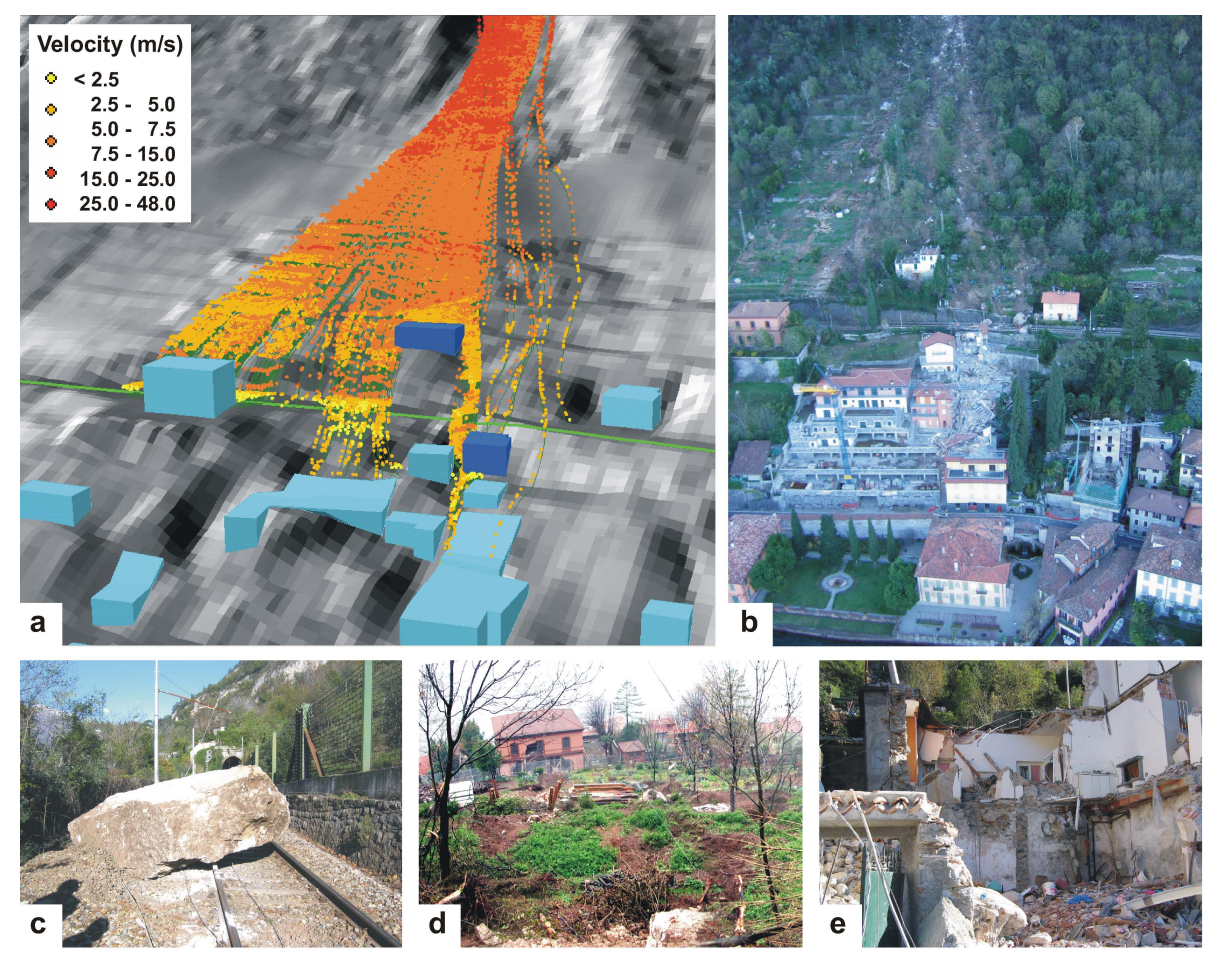

Fig. 5. Calibration of the 3D rockfall numerical model by back analysis of the 2004 event. (a) Simulated trajectories represented as points classified by local block velocity; (b) block paths mapped after the event; (c) runout of single blocks; (d) impact and rolling scours; (e) damage to structures.

which were derived from the literature (Agliardi and Crosta, 2003; Frattini et al., 2008). Rockfall sources have been defined by detecting bedrock outcrops on steep terrains, failure evidences, rockfall accumulations, and collecting available geomechanical and historical data (Agostoni et al., 2000). A total of 21463 source cells $\left(85852 \mathrm{~m}^{2}\right.$, about $16 \%$ of the model area) were identified, mostly corresponding to steep rocky cliffs above $600 \mathrm{~m}$ a.s.l. (average slope: $60^{\circ}$; standard deviation of slope: $10.5^{\circ}$ ).

The model was calibrated through a detailed back analysis of the 2004 rockfall event, for which the source area location was well known (Fig. 3). The trajectories of 2750 spherical blocks were simulated (Fig. 5a), with block radius varying between 0.5 and $3 \mathrm{~m}$ according to a negative exponential probability density function. These values correspond to volumes in the range $0.5-113 \mathrm{~m}^{3}$, in agreement with block sizes observed in the field. In order to account for natural variability and the stochastic nature of the rockfall process, all the relevant parameters were varied according to different probability density distributions. In particular, according to the published literature (Azzoni et al., 1995) a normal probability density distribution was assigned to the restitution and friction coefficients ( $3 \sigma$ values in Table 1). Calibrated values of model parameters (Table 1) were obtained by fitting the runout and kinematics of simulated trajectories to detailed event data mapped in the field soon after the event. These included mapped block trajectories and runout, extent of the impacted area, impact and rolling scours, and block-structure interactions, i.e. damage or energy absorption (Fig. 5).

\subsection{Rockfall frequency and probability of impact}

The annual frequency of rockfall events, $N_{j}$ (i.e. a proxy of rockfall onset temporal probability) must be defined with reference to specific event magnitude classes, as for flood or earthquake events. This requires knowing or assuming the relationship which describes the magnitude-frequency distribution of rockfall events in a given area characterised by specific geological and geomorphological features. For landslides, different magnitude-frequency relationships both in terms of area and volume have been used (Stark and Hovius, 2001; Guzzetti et al., 2002; Malamud et al., 2004). As to rockfalls, several authors (Hungr et al., 1999; Dussauge et al., 2003; Malamud et al., 2004) demonstrated that the magnitude-cumulative frequency (MCF) distribution of events in given volume classes $j$ can be described by a power law in the form:

$\log N(V)=N_{0}+b \cdot \log V$

where $N(V)$ is the cumulative annual frequency of rockfall events exceeding a given volume, $N_{0}$ is the total annual number of rockfall events, and $b$ is the power law exponent. The annual frequency of rockfall events in a given volume class 
Table 1. Mean $(\mu)$ and $3 \sigma$ values of the rolling friction $(\tan \Phi r)$ and normal and tangential impact energy restitution $\left(e_{n}, e_{t}\right)$ coefficients, used to set up the Fiumelatte rockfall models assuming a truncated gaussian PDF. Parameters were calibrated through the back analysis of the 2004 rockfall event. The different terrain classes have been obtained by unique condition combination of superficial lithology and land use as mapped in the field (Fig. 4).

\begin{tabular}{lcccccc}
\hline & \multicolumn{2}{c}{$\tan \left(\Phi_{r}\right)$} & \multicolumn{2}{c}{$e_{n}$} & \multicolumn{2}{c}{$e_{t}$} \\
terrain class & $\mu$ & $3 \sigma$ & $\mu$ & $3 \sigma$ & $\mu$ & $3 \sigma$ \\
\hline Embankment fill material & 0.45 & 0.023 & 0.35 & 0.018 & 0.70 & 0.035 \\
Built area & 0.45 & 0.023 & 0.35 & 0.018 & 0.80 & 0.040 \\
Colluvial deposit, grass covered & 0.45 & 0.023 & 0.35 & 0.018 & 0.80 & 0.040 \\
Talus slope, bare & 0.30 & 0.015 & 0.40 & 0.020 & 0.85 & 0.043 \\
Talus slope, bush covered & 0.35 & 0.018 & 0.40 & 0.020 & 0.80 & 0.040 \\
Talus slope, forested & 0.35 & 0.018 & 0.40 & 0.020 & 0.80 & 0.040 \\
Subcropping rock, forested & 0.40 & 0.020 & 0.65 & 0.033 & 0.75 & 0.038 \\
Outcropping rock, bare & 0.30 & 0.015 & 0.70 & 0.035 & 0.85 & 0.043 \\
Outcropping rock, forested & 0.35 & 0.018 & 0.70 & 0.035 & 0.80 & 0.040 \\
\hline
\end{tabular}

Table 2. Block volume classes considered in the risk analysis, and expected frequencies of related events according to the adopted magnitude-frequency curve.

\begin{tabular}{cccc}
\hline $\begin{array}{c}\text { Volume class } j \\
-\end{array}$ & $\begin{array}{c}\text { Volume range } \\
\mathrm{m}^{3}\end{array}$ & $\begin{array}{c}\text { Incremental annual frequency, } N j \\
\text { (events/year) }\end{array}$ & $\begin{array}{c}\text { Return period } \\
\text { (years) }\end{array}$ \\
\hline 1 & $0.001 \div 0.01$ & 6.11 & 0.16 \\
2 & $0.01 \div 0.1$ & 2.38 & 0.42 \\
3 & $0.1 \div 1$ & 0.92 & 1.09 \\
4 & $1 \div 10$ & 0.36 & 2.78 \\
5 & $10 \div 100$ & 0.14 & 7.14 \\
\hline
\end{tabular}

$j$ (i.e. $N_{j}$ ) can be derived from MCF curves by subtracting the cumulative frequencies for each considered volume class, according to the approach by Hungr et al. (1999). The parameters of MCF curves themselves have no universal significance, although the exponent $b$ has been found to vary in a quite narrow range, i.e. $-0.7<b<-0.4$ (Hungr et al., 1999; Dussauge et al., 2003), and should be based on complete local rockfall inventories. Since a site-specific event catalogue for the Fiumelatte area is lacking, a value of $b=-0.41$ was derived from the literature (i.e. value for carbonate rocks proposed by Dussauge et al., 2003). A conservative estimate of $N_{0}=10$ was derived from available historical and geomorphological information for the entire $800 \mathrm{~m}$ long cliff span.

In order to evaluate rockfall risk according to Eq. (6), we considered five block volume classes $j$ (Table 2), covering the volume range $0.001-100 \mathrm{~m}^{3}$. Larger rockfall volumes are prone to fragmentation soon after detachment, as suggested by the 2004 event dynamics, and were not considered as single block volumes.

For each protection scenario (S0, S1 and S2) and for each volume class (Table 2) rockfall numerical modelling was performed over the entire exposed area (Fig. 6), by simulating 214630 trajectories (i.e. 10 blocks from each source cell).
For scenarios S1 and S2, the original LIDAR topography was modified by merging detailed DEM specifically set up from countermeasure design plans. These were generated in $\operatorname{ArcGIS}^{T M}$ as TINs (Triangular Irregular Networks) and then converted to raster at the same resolution as the LIDAR topography. At embankment locations, the restitution and rolling friction coefficients were also modified accordingly.

Modelling results relevant to risk analysis (Fig. 6) included the frequency and kinetic energy of blocks reaching each model cell. For each element at risk and block volume class, the reach probability $P(T \mid L)_{i j}$ was evaluated as the ratio of the total number of blocks reaching each building $i$ and the total number of trajectories simulated by the model (Fig. 7), assuming a constant rockfall susceptibility over the entire cliff. Finally, the impact probability $P(I)_{i j}$ of a block in the volume class $j$ on the building $i$ is given by multiplying the annual frequency of events in the volume class $j\left(N_{j}\right)$ by the reach probability $P(T \mid L)_{i j}$ (Fig. 7). For persons inside buildings, the impact probability was scaled according to a spatial temporal probability of 0.5 .

\subsection{Vulnerability}

Quantitative risk assessment requires evaluating the vulnerability of single elements at risk. This has been defined by several authors in terms of both societal vulnerability (Glade, 2003) and physical vulnerability (Uzielli et al., 2008). The latter is a scenario-specific parameter defined as "the degree of loss to a given element or a set of elements within the area affected by the hazard" (ISSMGE TC32, 2004). In the field of natural hazards, well-established methods for the estimation of physical vulnerability have been developed for earthquake (Kappos, 2006) and flood risk (USACE, 1996). For landslides, the quantitative assessment of vulnerability is made difficult by the lack of accurate damage data and by the inherent complexity of landslide kinematics and interaction 


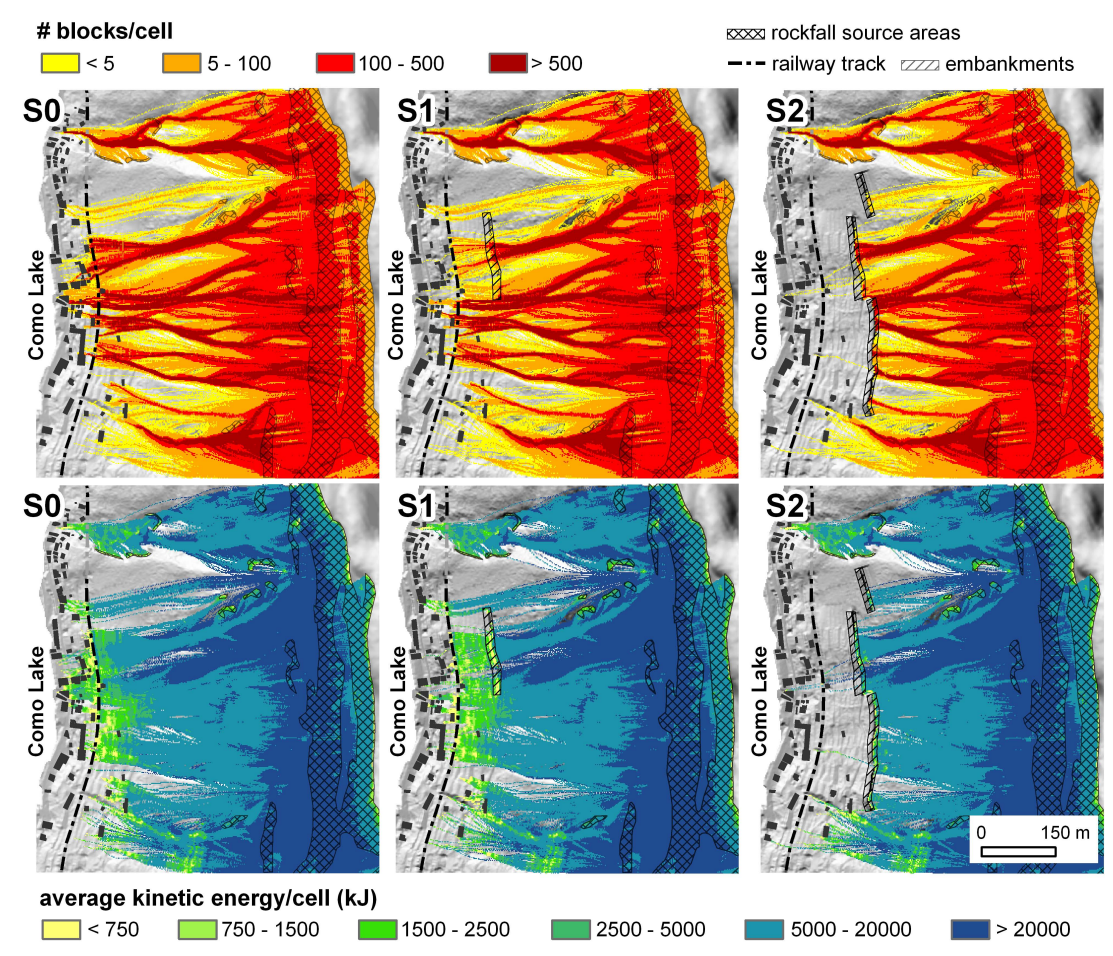

Fig. 6. Results of 3D rockfall numerical modelling performed for the protection scenarios S0, S1 and S2, portrayed in raster format in terms of number of blocks reaching each model cell (above) and average kinetic energy/cell in kJ (below). Reported examples are for volume class $j=5$ (Table 2).

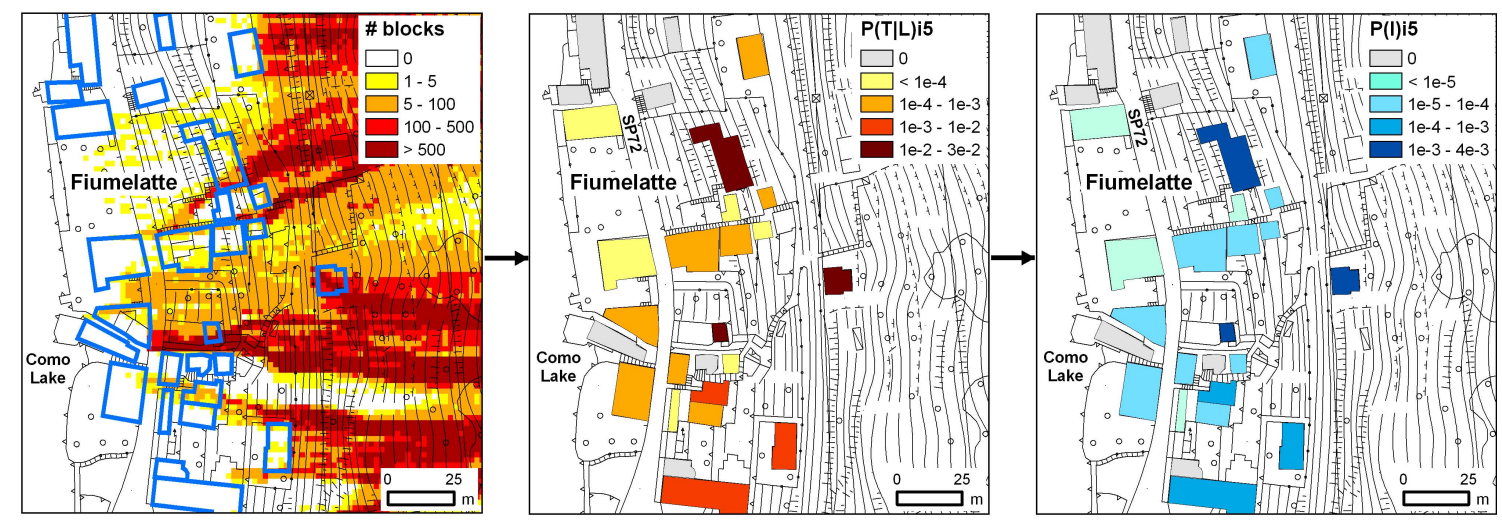

Fig. 7. Estimation of the probability of impact on buildings from numerical modelling results. The total number of blocks reaching each building $i$ was used to compute the reach probability. This was combined with the annual frequency of rockfall events in each volume class $j$ to obtain the probability of impact. Reported example is for protection scenario S0 and for volume class $j=5$ (Table 2 ).

with different types of structures (Glade, 2003), although some advanced methods have been proposed (Uzielli et al., 2008; Kaynia et al., 2008).

For rockfalls, physical vulnerability of elements at risk or protection structures is a function of the kinetic energy of rockfall impacts (Straub and Schubert, 2008) and should be expressed by vulnerability curves derived by statistically sound databases of damage to specific categories of structures impacted by rockfalls, which are rarely available. Nevertheless, a quantitative although simple estimation of physical vulnerability is required to perform Quantitative Risk Analysis. Thus, we evaluated the physical vulnerability of buildings in the Fiumelatte area through an empirical approach based on the analysis of detailed event data collected soon after the 2004 disaster. In particular, we linked the impact energy values derived by numerical modelling with the damages observed in the field.

For vulnerability assessment purposes, the energy of rockfall impacts against each building damaged in 2004 was calculated from velocity values simulated by numerical back 


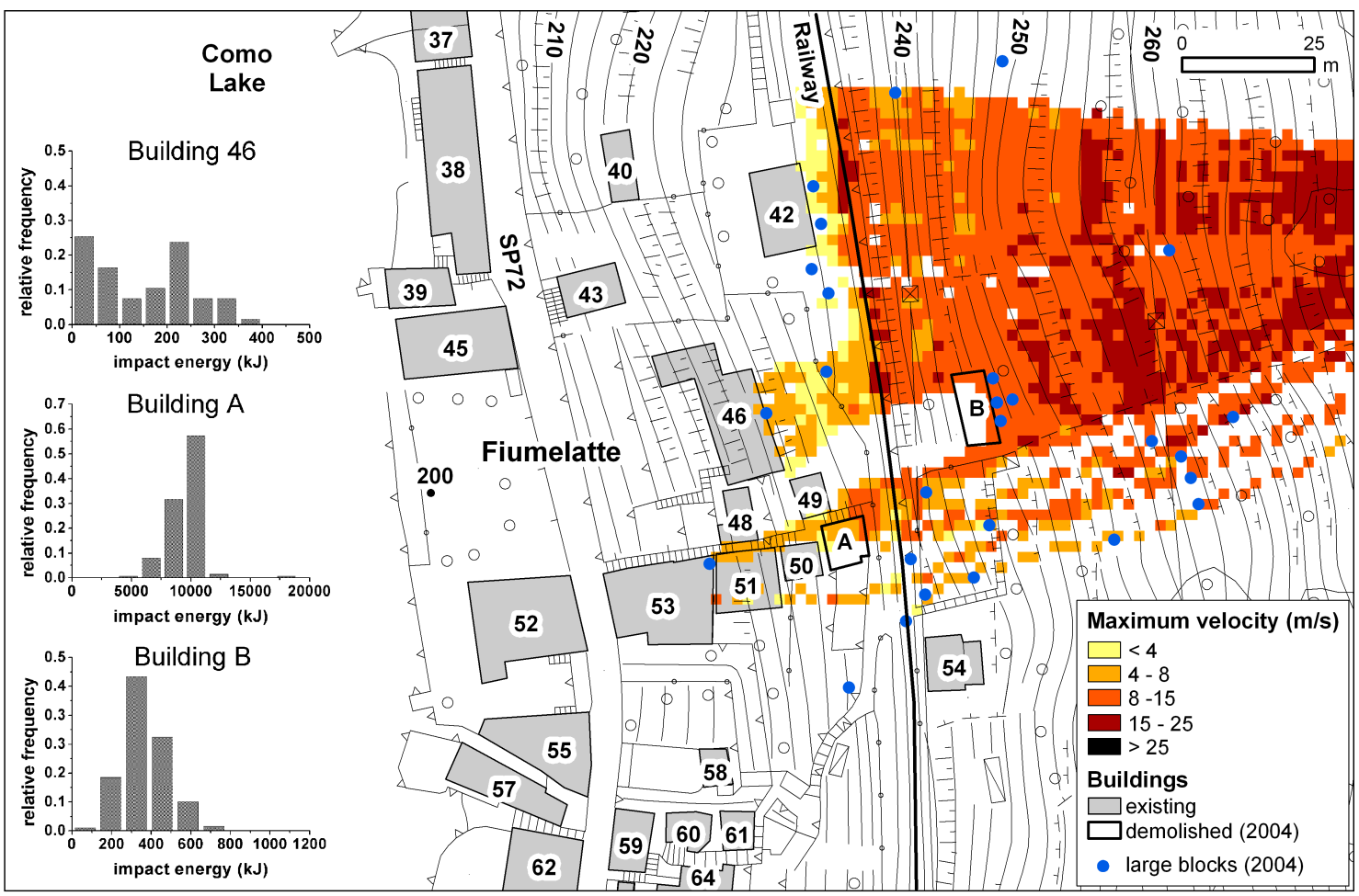

Fig. 8. Spatial distribution of block velocity derived from the numerical back analysis of the 2004 rockfall event. For vulnerability assessment, the statistical distribution of the impact energy of observed blocks against each impacted building (examples reported as histograms) was evaluated from simulated velocity values.

analysis of the event (Fig. 8). This allowed to account for the mass of specific blocks causing observed damage (Figs. 2, 5 and 9). In addition, local rockfall kinematics and the pattern of block-structure interaction were evaluated by different experts, in order to refine the most probable range of impact energy associated to observed damage. The degree of loss suffered by each building impacted by the 2004 event was estimated by an engineering evaluation of structure type (e.g. masonry or reinforced concrete frame), damaged structural elements (e.g. concrete bearing frame, bearing or partition walls), functional damage and repairability (Fig. 9). A site-specific empirical vulnerability function was obtained by fitting damage and impact energy values through a sigmoidal function (Fig. 9) in the form:

$V(E)=1-\frac{1.358}{1+e^{\frac{E-129000}{120300}}}$

where $V$ is the fractional degree of loss, ranging 0 to 1 , and $E$ is the impact energy in Joule.

The physical vulnerability of human life to rockfalls is very difficult to estimate since there is a lack of damage statistics, and none of the few published studies expressed it in the form of vulnerability curves (Cruden, 1997; Hungr et al., 1999; Corominas et al., 2005). For the present purposes, we assumed that the vulnerability of persons inside buildings (i.e. the degree of loss in terms of injury or death suffered by an occupant given that a block impacted a building) shows the same dependence on impact energy (i.e. the same vulnerability function) as the buildings.

\subsection{Risk analysis results}

Knowing the impact energies computed by numerical modelling (Fig. 6) for each protection scenario (S0, S1 and S2) and each volume class $j$, we were able to derive the degree of loss of each element at risk (Fig. 10). This was combined with the impact probability and the value of the elements at risk according to Eq. (6), allowing to compute the risk to buildings (Fig. 10) and to persons inside buildings in terms of annual expected costs (in Euro). Finally, we computed the total annual expected cost for each of the three protection scenarios (Fig. 11) as the sum of expected costs estimated for each block volume class and element at risk. The statistical variability of simulated energy of impact on each building was accounted for by providing lower and upper bound risk estimates considering the minimum, average and maximum computed impact energies, respectively (Fig. 12).

Analysis results in terms of total annual expected costs, including risk to buildings and persons inside, can be portrayed by both maps and plots (Figs. 11 and 12). In the unprotected scenario (S0) a $250 \mathrm{~m}$ wide corridor (including the sector impacted in 2004) and the Pino area to the south (Fig. 11) are 

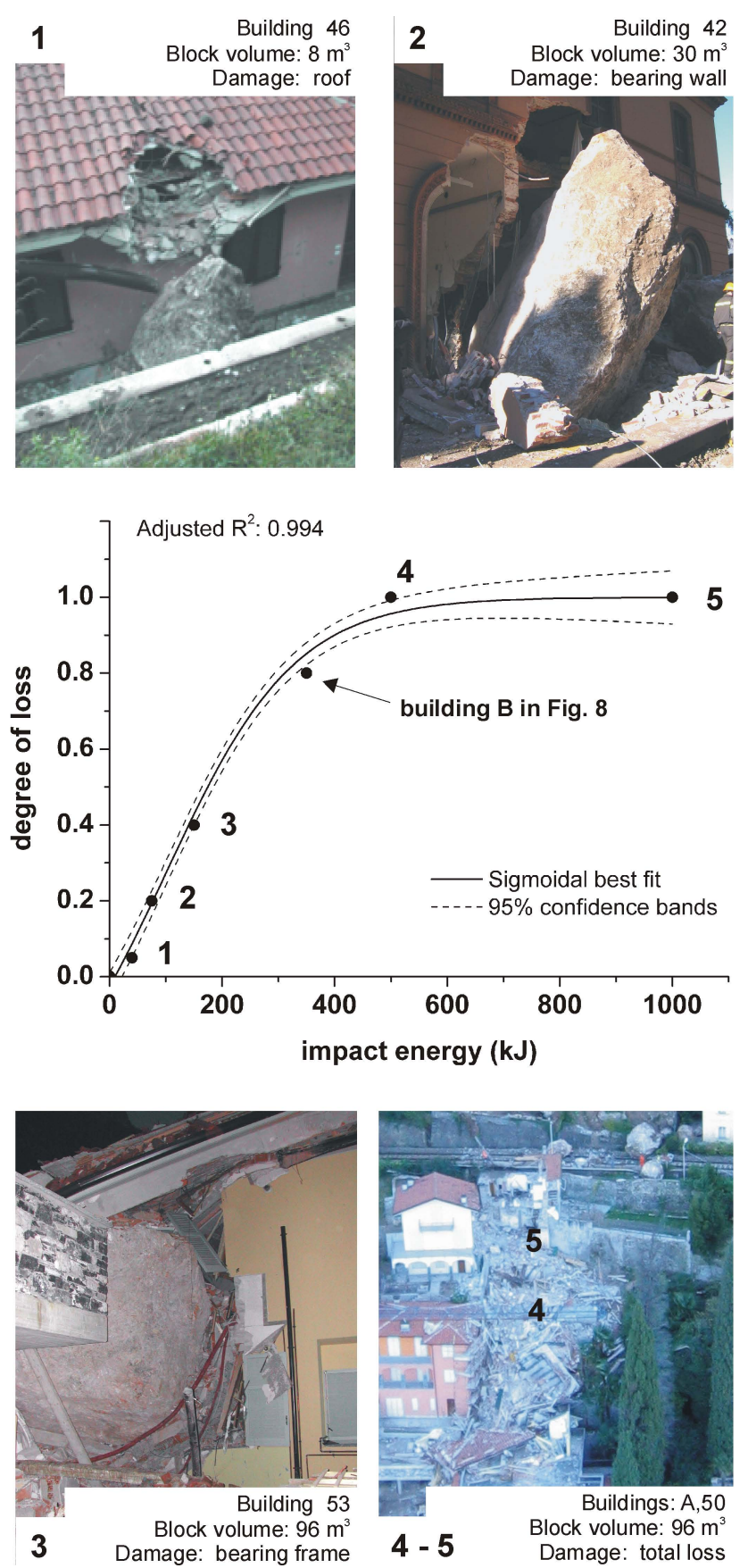

Fig. 9. Empirical assessment of the degree of loss suffered by structures impacted by the 2004 rockfall event, based on field observations carried on soon after the event. These data were combined to recalculated impact energy values (Fig. 8) to establish a sitespecific empirical vulnerability function by fitting damage-energy data through a sigmoidal function.
Table 3. Residual/initial risk ratio of protection scenarios S1 (provisional embankment) and S2 (long-term protection embankments), estimated for total risk, risk to buildings and risk to persons in buildings, respectively. The ratio provides a useful tool to evaluate the relative expected technical performance of different protective actions.

\begin{tabular}{lcccc}
\hline & Risk: & Buildings & Persons & Total \\
\hline \multirow{3}{*}{ S1-S0 } & Minimum & 0.44 & 0.53 & 0.50 \\
& Average & 0.39 & 0.46 & 0.44 \\
& Max & 0.27 & 0.32 & 0.31 \\
S2-S0 & Minimum & 0.01 & 0.02 & 0.02 \\
& Average & 0.01 & 0.01 & 0.01 \\
& Max & 0.01 & 0.01 & 0.01 \\
S2-S1 & Minimum & 0.03 & 0.03 & 0.03 \\
& Average & 0.02 & 0.02 & 0.02 \\
& Max & 0.02 & 0.02 & 0.02 \\
\hline
\end{tabular}

exposed to a total annual risk of about 98000 Euro (average value) and up to 428000 Euro (maximum; Fig. 12). This was considered unacceptable in societal terms by the authorities in charge of civil protection. Moreover, the estimated annual probability of loss of life (PLL), i.e. the annual probability for an individual to suffer complete $\operatorname{loss}(V(E)=1$ in Eq. 8), reaches $7.5 \times 10^{-3}$, exceeding the limit value of $10^{-4}$ suggested by risk acceptability guidelines established in Hong Kong for rockfalls (GEO, 1998). When the provisional embankment (S1) is introduced in the analysis, total annual risk is significantly reduced in the 2004 damage area (Fig. 11), with a total annual expected cost lowered to about 43000 Euro (average) and 130000 Euro (maximum). Nevertheless, in this scenario the southern part of Fiumelatte and the Pino area remain unprotected, with an estimated annual PLL up to $8 \times 10^{-4}$. The highest degree of protection is achieved in the scenario S2, with some residual risk only affecting the Pino area, south of Fiumelatte (Figs. 11 and 12) and an estimated annual PLL below $10^{-4}$ for all the exposed individuals. The expected technical performance of the existing and envisaged mitigation actions S1 and S2 was further evaluated by computing the ratio of the residual risk (i.e. the annual expected cost estimated in a given protected scenario) to the initial risk, corresponding to the unprotected scenario S0. This ratio, computed with respect to the minimum, average and maximum estimated risks (Table 3), outline the very good expected performance of the $\mathrm{S} 2$ option (planned series of embankments) with respect to the one of S1 (provisional embankment). 

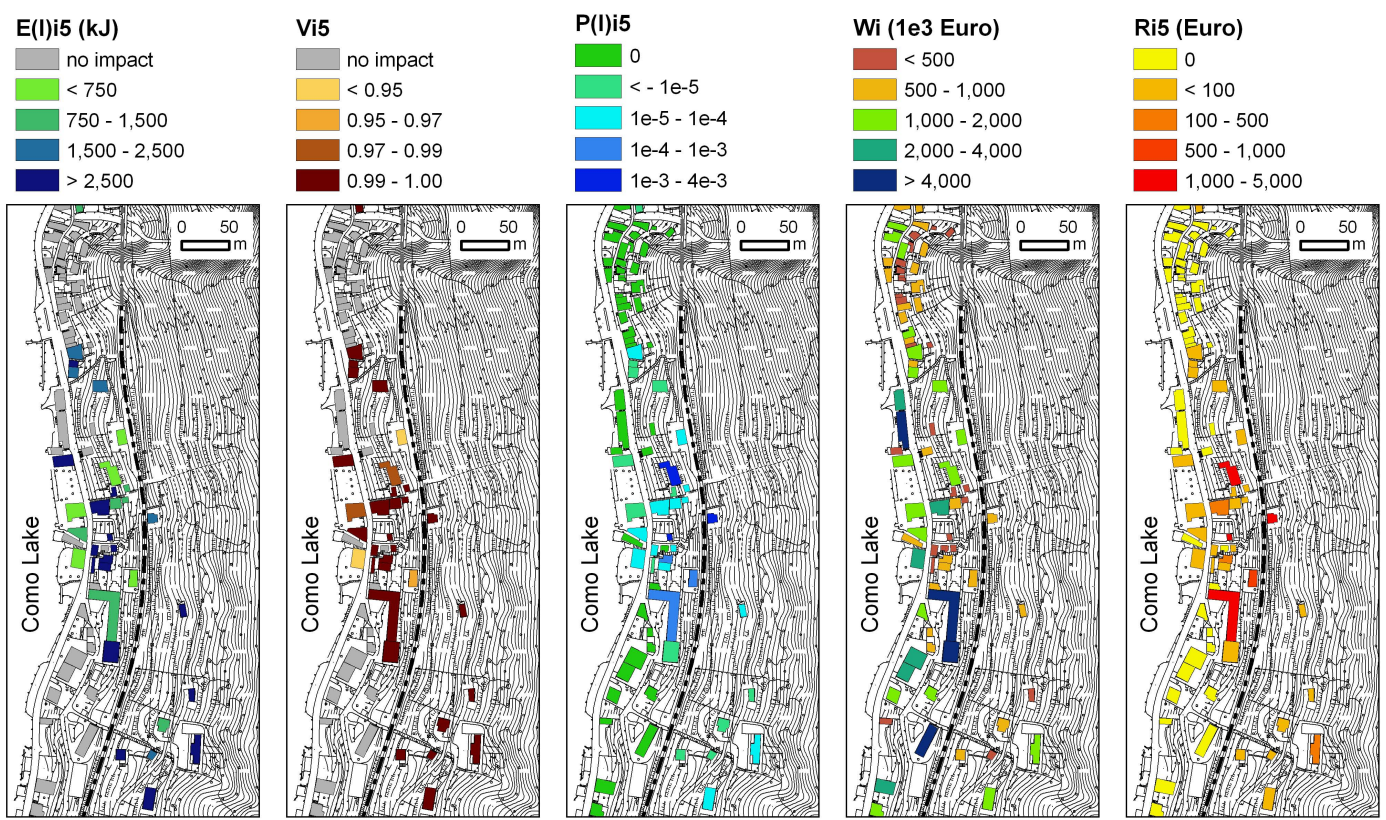

Fig. 10. Evaluation of the risk for buildings (i.e. annual expected cost in Euro) by combination of vulnerability (i.e. function of simulated impact energy on each building $i$ ), probability of impact and value. The reported example is for protection scenario S0, volume class $j=5$ (Table 2) and average computed impact energies.
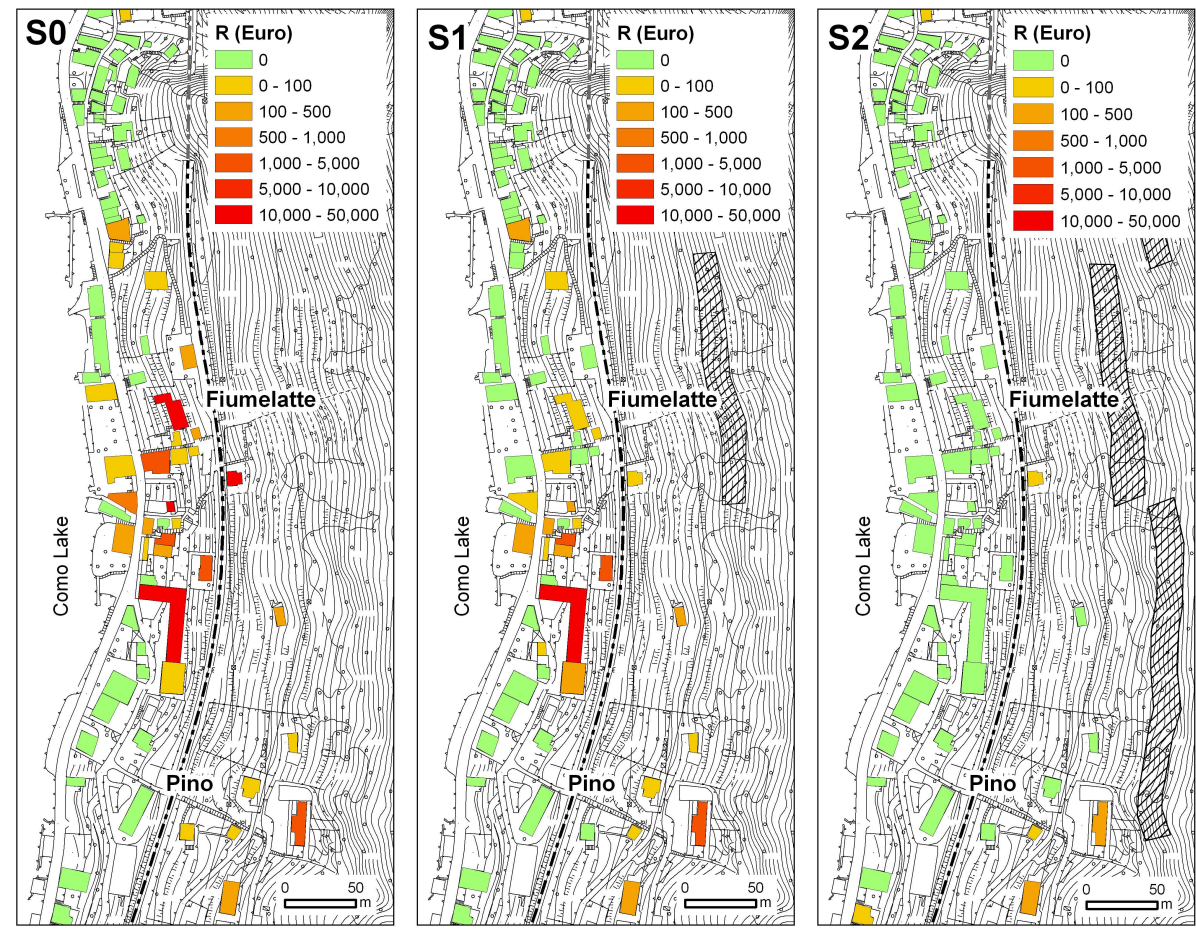

Fig. 11. Total risk (i.e. annual expected cost in Euro) computed for single buildings and persons inside, including the contribution of all the considered volume classes, for each considered scenario (S0, S1 and S2). Maps clearly show the spatial distribution of risk and the degree of risk reduction provided by different protection options. The reported example is for risk computed using average values of impact energy on each building. 

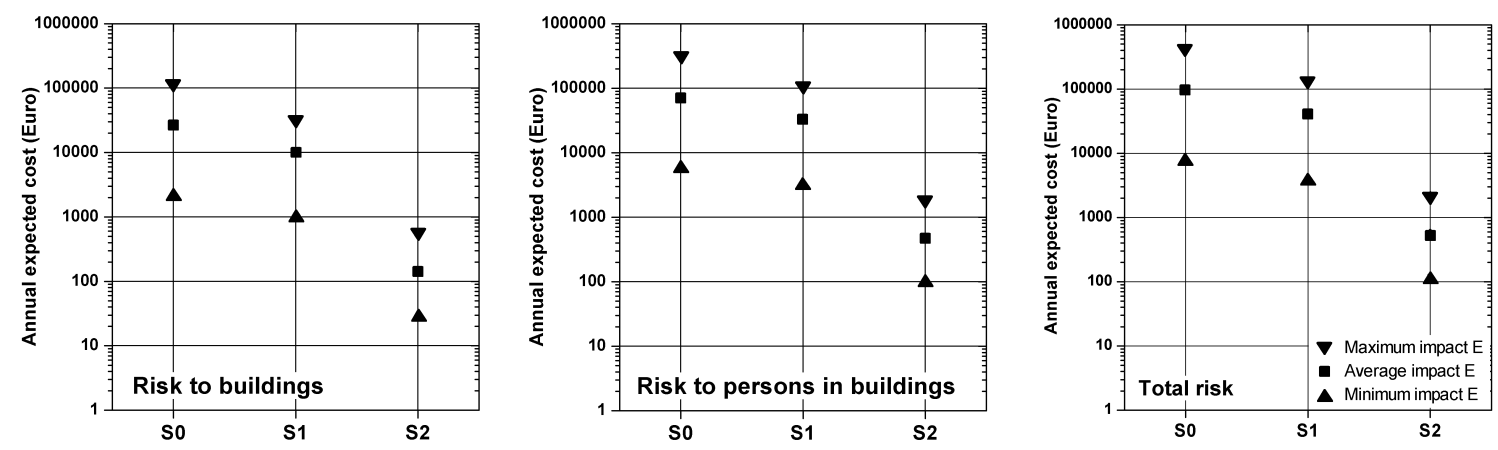

Fig. 12. Summary of the annual expected costs (in Euro) for rockfall risk to buildings, risk to persons inside buildings, and total risk, computed for the whole study area. Expected costs have been computed for three scenarios (S0, S1, S2) considering the maximum, average, and minimum impact kinetic energy estimated by numerical modelling at each impacted building.

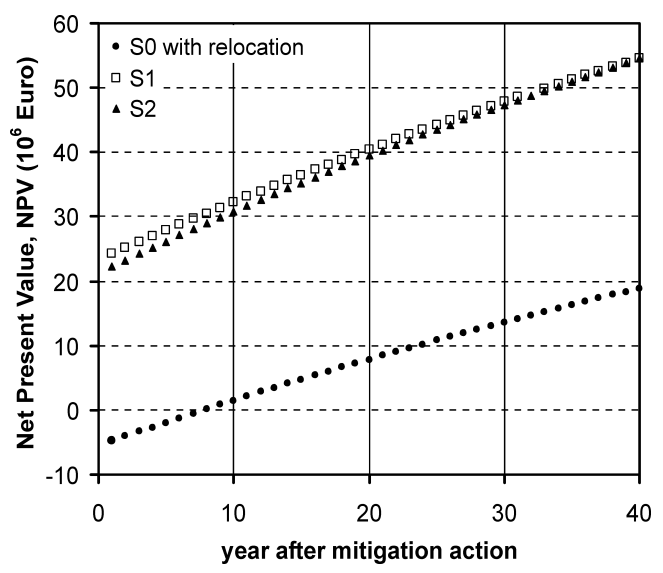

Fig. 13. Results of the cost-benefit analysis of different mitigation options (S0 with relocation of most exposed buildings, S1, S2). The Net Present Value (NPV) of benefits and costs related to the considered protection scenarios was computed at different times from the deployment of mitigation actions.

Finally, in order to evaluate the cost efficiency of the mitigation strategies (FEMA, 1996), a cost-benefit analysis of the different strategies was performed by calculating the Net Present Value (NPV):

$\mathrm{NPV}=\sum_{t=o}^{T} \frac{B_{t}}{(1+r)^{t}}-\sum_{t=o}^{T} \frac{C_{t}}{(1+r)^{t}}$

where $B_{t}$ is the benefit at time $t, \mathrm{C}_{t}$ is the cost at time $t$, and $r$ is the discount rate.

The NPV values calculated for the protection scenarios S1 and S2 were compared to the most conservative and expensive strategy consisting in the complete relocation of the buildings most exposed at risk in the scenario S0. For costbenefit analysis, only direct costs were considered. These derive from: the reconstruction of new houses in the relocation scenario; the damages of existing houses in case of event, the damage to injured people. Benefits derive from the economic returns of either undamaged or reconstructed houses, quantified by the rent interest. For the computation of actualized benefits and costs a discount rate of $4 \%$ (50years swap rate), an inflation rate of $2 \%$ (i.e. the European Central Bank objective), and a rent interest of $5 \%$ were used. NPV was evaluated at different times after the achievement of the mitigation action (Crosta et al., 2005), ranging from 1 to 40 years. The results show that both protection strategies S1 and S2 are largely preferable over the relocation of endangered houses (Fig. 13). Moreover, the Net Present Value of the two strategies is very similar, thus demonstrating a similar cost efficiency.

\section{Discussion}

Quantitative Risk Analysis (Fell et al., 2005) is becoming widespread in the field of natural hazards, progressively overcoming qualitative approaches (e.g. heuristic methods). Quantitative approaches represent requisite tools to evaluate the acceptability of risk, establish mitigation targets, and plan, design and evaluate both structural and non-structural protective actions. Nevertheless, when dealing with landslide hazards a quantitative assessment of risk is affected by a variety of difficulties related to: evaluating the occurrence probability of landslides both in space (i.e. susceptibility) and in time (i.e. recurrence), modelling runout processes and the interactions between landslides and elements at risk, and accounting for the uncertainties due to inherently complex physical processes and the stochastic variability of all the relevant parameters (Crosta and Agliardi, 2003; Glade, 2003; Hungr et al., 2005). We showed that integrating advanced process-based modelling techniques in a physically sound quantitative risk assessment framework can provide tools to overcome some of these difficulties, even when considering long runout landslides with a complex dynamics as rockfalls (Agliardi and Crosta, 2003; Crosta and Agliardi, 2004). In particular, the proposed risk assessment procedure allows to account for the spatially distributed nature of rockfall processes, for which both the probability of impact on different element at risk and intensity show sharp variations 
both along and transversally to block trajectories. Moreover, accurate 3D numerical modelling provides a suitable tool to analyze the distribution of rockfall dynamic quantities (e.g. kinetic energy) at the location of single elements at risk, thus supporting a quantitative assessment of vulnerability. Finally, the capability of modelling different protection scenarios by introducing countermeasures and elements at risk in a GIS environment allows a repeatable and sound evaluation of the residual risk.

A major limitation to the application of the proposed risk assessment procedure in practice is the lack of statistically representative historical catalogues of rockfall events allowing a sound characterization of the frequency distribution of rockfall volumes for specific sites. In particular, assumptions made on the values of the power law exponent $b$ and the total annual frequency of event $N_{0}$ (Hungr et al., 1999) strongly affect the results of risk analysis in terms of annual expected costs over an order of magnitude, as demonstrated by the example sensitivity analysis in Fig. 14. In a similar way, risk estimates depend on the adopted vulnerability functions, which should be based on probabilistic analyses of damage data recorded in statistically representative databases of damage events affecting different categories of elements at risk. Unfortunately, such databases are mostly unavailable for rockfall problems, and can rarely be collected at a site specific scale. Moreover, data required for a detailed quantification of the value of elements at risk (e.g. insured replacement value of buildings; Fuchs and McAlpin, 2005) are not always accessible depending on the type of impacted elements and regulations in force in different countries, thus introducing further uncertainty in the resulting expected costs.

The presented case study is a typical one for which the aforementioned information is not available. Nevertheless, we showed that advanced numerical modelling techniques can be used to set up a sound risk assessment procedure which can be enforced at different levels of detail depending on the available data. We suggest that, when detailed data are available to establish site-specific, statistically sound magnitude-frequency relationships and vulnerability functions, reliable estimates of absolute values of total expected costs can be obtained and supported by sensitivity analyses. Otherwise, conservative assumptions on the relevant parameters (e.g. MCF power law exponent or total annual number of rockfall events) can be used, provided that the sensitivity of risk calculations to the assumptions made has been evaluated (Fig. 14). Much effort should then be spent in setting up high-resolution numerical models allowing for a reliable assessment of impact probability and empirically-derived vulnerability. However, even when detailed data is not available nor can be collected in a time and cost-effective way, the suggested risk analysis procedure proved to be effective in order to compare different risk scenarios, allowing a meaningful evaluation of the technical performance of different mitigation options.

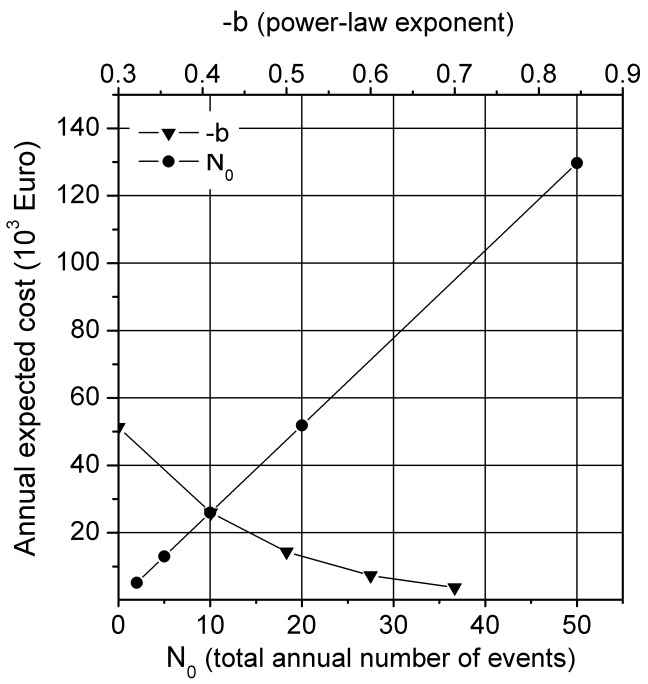

Fig. 14. Sensitivity of the computed total risk for buildings (S0 scenario, average kinetic energy case) to the main parameters of the MCF curve used to estimate rockfall onset frequency, i.e. total annual number of events $\left(N_{0}\right)$ and power law exponent (b).

\section{Conclusions}

This study shows the possibility to achieve quantitative evaluation of rockfall risk as an input for the design and costbenefit analysis of different mitigation scenarios. A single modelling tool has been used to assess the physical components of risk, namely: hazard, probability and energy of impacts on structures. These are mandatory data for a complete risk assessment through the evaluation of the expected losses. With respect to existing rockfall risk analysis procedures, the proposed one supported by 3D numerical modelling proved (1) to be more suitable for spatially distributed risk problems, (2) to be able to integrate all stages of risk assessment, and (3) to reduce the number of assumptions on the physical components of risk.

Although affected by uncertainties due to the lack of statistically sound catalogues of both rockfall events and damages, the proposed approach allows a sound estimation of residual risk, which is required to assess both the technical efficiency (i.e. capability of intercepting incoming blocks) and the cost efficiency (i.e. cost/benefit) of different mitigation options.

Acknowledgements. We are grateful to P. Florean, and F. Omegna for their assistance in the field, M. Ceriani and the Regione Lombardia Civil Protection staff for making available event data, aerial photos and the LIDAR topography, and C. Adamoli for providing event loss data. The paper benefited from the reviews by L. Dorren and an anonymous referee. The research has been carried out in the framework of the SAFELAND project ("Living with landslide risk in Europe: Assessment, effects of global change, and risk management strategies"), European Commission 7th Framework Programme.

Edited by: A. Volkwein

Reviewed by: L. Dorren and another anonymous referee 


\section{References}

Agliardi, F. and Crosta, G.: High resolution three-dimensional numerical modelling of rockfalls, Int. J. Rock Mech. Min., Sci., 40, 455-471, 2003.

Agostoni, S., Cantone, G., Laffi, R., Ratti, R., and Sciunnach, D.: Centri abitati instabili della Provincia di Lecco. Regione Lombardia - CNR. GNDCI, publication n. 2066, 165 pp., 2000.

Azzoni, A., La Barbera, G., and Zaninetti, A.: Analysis and prediction of rock falls using a mathematical model, Int. J. Rock Mech. Min. Sci., 32, 709-724, 1995.

Barret, R. K. and Pfeiffer, T.: Rock fall modeling and attenuator testing, US Department of Transportation, Federal Highway Administration, Final Report, 107 pp., 1989.

Budetta, P.: Assessment of rockfall risk along roads, Nat. Hazards Earth Syst. Sci., 4, 71-81, 2004,

http://www.nat-hazards-earth-syst-sci.net/4/71/2004/.

Bunce, C. M., Cruden, D. M., and Morgenstern, N. R.: Assessment of the hazard from rock fall on a highway, Can. Geotech. J., 34, 344-356, 1997.

Cancelli, A. and Crosta, G. B.: Rockfall hazard and risk mapping, in: Proceedings 7th International Conference and Field Workshop on Landslides, edited by: Novosad, S. and Wagner, P., Czech-Slovak Rep., Balkema, 69-76, 1993.

Corominas, J., Copons, R., Moya, J., Vilaplana, J. M., Altimir, J., and Amigò, J.: Quantitative assessment of the residual risk in a rockfall protected area, Landslides, 2, 343-357, 2005.

Crosta, G. B. and Agliardi, F.: A methodology for physically based rockfall hazard assessment, Nat. Hazards Earth Syst. Sci., 3, 407-422, 2003,

http://www.nat-hazards-earth-syst-sci.net/3/407/2003/.

Crosta, G. B. and Agliardi, F.: Parametric evaluation of 3D dispersion of rockfall trajectories, Nat. Hazards Earth Syst. Sci., 4, 583-598, 2004,

http://www.nat-hazards-earth-syst-sci.net/4/583/2004/.

Crosta, G. B., Agliardi, F., Frattini, P., and Imposimato, S.: A threedimensional hybrid numerical model for rockfall simulation, Geophys. Res. Abstr., 6, 04502, Sref-ID:1607-7962/gra/EGU04A-04502, 2004.

Crosta, G. B., Frattini, P., Fugazza, F., Caluzzi, L., and Chen, J.: Cost-benefit analysis for debris avalanche risk management, in: Landslide Risk Management, edited by: Hungr, O., Fell, R., Couture, R., Eberhardt, E., 517-524, 2005.

Crosta, G. B., Frattini, P., Imposimato, S., and Agliardi, F.: Modelling vegetation and fragmentation effects on rock falls, Geophys. Res. Abstr., 8, 07694, Sref-ID:1607-7962/gra/EGU06-A07694, 2006.

Cruden, D. M.: Estimating the risks from landslides using historical data, in: Landslide risk assessment, edited by: Cruden, D. M. and Fell, R., Balkema, A. A., Rotterdam, 177-184, 1997.

Derron, M.-H., Jaboyedoff, M., and Blikra, L. H.: Preliminary assessment of rockslide and rockfall hazards using a DEM (Oppstadhornet, Norway), Nat. Hazards Earth Syst. Sci., 5, 285-292, 2005 ,

http://www.nat-hazards-earth-syst-sci.net/5/285/2005/.

Di Prisco, C. and Vecchiotti, M.: A rheological model for the description of boulder impacts on granular strata, Geotechnique, 56, 469-482, 2006.

Dussauge, C., Grasso, J. R., and Helmstetter, A.: Statistical analysis of rockfall volume distributions: implications for rockfall dynamics, J. Geophys. Res., 108(B6), 2286, doi:10.1029/2001JB000650, 2003.

Fell, R., Ho, K. K. S., Lacasse, S., and Leroi, E.: A framework for landslide risk assessment and management. In: Landslide Risk Management, edited by: Hungr, O., Fell, R., Couture, R., Eberhardt, E., Taylor and Francis, London, 3-26, 2005.

Fell, R., Corominas, J., Bonnard, C., Cascini, L., Leroi, E., and Savage, W. Z.: Guidelines for landslide susceptibility, hazard and risk zoning for land use planning, Eng. Geol., 102, 85-98, 2008.

FEMA (U.S. Federal Emergency Management Agency): How to determine cost-effectiveness of Hazard Mitigation Projects. A new process for expediting application reviews, FEMA Mitigation Directorate, Washington DC, 1996.

Frattini, P., Crosta, G., Carrara, A., and Agliardi, F.: Assessment of rockfall susceptibility by integrating statistical and physicallybased approaches, Geomorphology, 94, 419-437, 2008.

Fookes, P. G. and Sweeney, M.: Stabilization and control of local rockfall and degrading rock slope, Q. J. Eng. Geol., 9, 37-55, 1976.

Fuchs, S. and McAlpin, M. C.: The net benefit of public expenditures on avalanche defence structures in the municipality of Davos, Switzerland, Nat. Hazards Earth Syst. Sci., 5, 319-330, 2005 , http://www.nat-hazards-earth-syst-sci.net/5/319/2005/.

GEO: Landslides and boulder falls from natural terrains: interim risk guidelines, GEO Report 75, Geotechnical Engineering Office, Civil Engineering Department, Honk Kong, 183 pp., 1998.

Glade, T.: Vulnerability assessment in landslide risk analysis, Die Erde, 134, 121-138, 2003.

Guzzetti, F., Malamud, B. D., Turcotte, D. L., and Reichenbach, P.: Power-law correlations of landslide areas in central Italy, Earth Planet. Sc. Lett., 195, 169-183, 2002.

Hungr, O. and Beckie, R. D.: Assessment of the hazard from rock fall on a highway: Discussion, Can. Geotech. J., 35, 409, doi:10.1139/cgj-35-2-409, 1998.

Hungr, O., Fell, R., Couture, R., and Eberhardt, E.: Landslide Risk Management, Taylor and Francis, London, 763 pp., 2005.

Hungr, O., Evans, S. G., and Hazzard, J.: Magnitude and frequency of rockfalls and rock slides along the main transportation corridors of south-western British Columbia, Can. Geotech. J., 36, 224-238, 1999.

ISSMGE TC32: Glossary of Risk Assessment Terms. Version 1. International Society of Soil Mechanics and Geotechnical Engineering, Technical Committee on Risk Assessment and Management, 7 pp., 2004 (available at www.engmath.dal.ca/tc32/ 2004Glossary_Draft1.pdf).

Jaboyedoff, M., Dudt, J. P., and Labiouse, V.: An attempt to refine rockfall hazard zoning based on the kinetic energy, frequency and fragmentation degree, Nat. Hazards Earth Syst. Sci., 5, 621-632, 2005 ,

http://www.nat-hazards-earth-syst-sci.net/5/621/2005/.

Jadoul, F. and Gaetani, M.: L'assetto strutturale del settore lariano centro-meridionale, Memorie della Società Geologica Italiana, 32, 123-131, 1986.

Jonkman, S. N.: Loss of life estimation in flood risk assessment. Theory and applications, PhD Thesis, Technical University of Delft, Delft, Netherlands, 354 pp., 2007.

Kaynia, A. M., Papatoma-Koehle, M., Neuhaeuser, B., Ratzinger, K., Wenzel, H., and Medina-Cetina, Z.: A Probabilistic assess- 
ment of vulnerability to landslide: Application to the village of Lichtenstein, Baden-Württemberg, Germany, Eng. Geol., 101, 33-48, 2008.

Kappos, A. J., Panagopoulos, G., Panagiotopoulos, C., and Penelis, G.: A hybrid method for the vulnerability assessment of R/C and URM buildings, B. Earthq. Eng., 4, 391-413, 2006.

Malamud, B. D., Turcotte, D. L., Guzzetti, F., and Reichenbach, P.: Landslide inventories and their statistical properties, Earth Surf. Proc. Land., 29, 687-711, 2004.

Mazzoccola, D. and Sciesa, E.: Implementation and comparison of different methods for rockfall hazard assessment in the Italian Alps, Proceedings 8th International Symposium on Landslides, Cardiff, Balkema, 2, 1035-1040, 2000.

Nichol, M. R. and Watters, R. J.: Comparison and effectiveness of rock fall mitigation techniques applied by states in the USA and Canada, Proceedings of the 20th Annual Eng. Geol. Soil Eng. Symposium, Boise, ID, 123-142, 1983.

Pfeiffer, T. and Bowen, T.: Computer simulation of rock falls, Bull. Assoc. Eng. Geol., 26, 135-146, 1989.

Pierson, L. A., Davis, S. A., and Van Vickle, R.: Rockfall Hazard Rating System Implementation Manual, Report FHWA-OREG-90-01, Federal Highway Administration, U.S. Department of Transportation, 1990.
Porter, K. A., Shoaf, K., and Seligson, H.: Value of injuries in the Northridge Earthquake, Earthq. Spectra, 22, 555-563, 2006.

Raetzo, H., Lateltin, O., Bollinger, D., and Tripet, J. P.: Hazard assessment in Switzerland - Code of practice for mass movements. B. Eng. Geol. Environ., 61, 263-268, 2002.

Ritchie, A. M.: Evaluation of rock fall, its control. HRB, Highway Research Record, 17, 13-28, 1963.

Schönborn, G.: Alpine tectonics and kinematic model of the Central Southern Alps, Mem. Sci. Geol. Univ. Padova, 44, 229-393, 1992.

Spang, R. M.: Protection against rockfall - stepchild in the design of rock slopes, Proceedings 6th International Congress on Rock Mechanics, Montreal, Canada, 551-557, 1987.

Stark, C. P. and Hovius, N.: The characterization of landslide size distributions. Geophys. Res. Lett., 28, 1091-1094, 2001.

Straub, D. and Schubert, M.: Modelling and managing uncertainties in rock-fall hazards, Georisk, 2, 1-15, 2008.

USACE (U.S. Army Corps of Engineers): Risk-based analysis for flood damage reduction studies, Engineering Manual 1110-21619, Washington D.C., 1996.

Uzielli, M., Nadim, F., Lacasse, S., and Kaynia, A. M..: A conceptual framework for quantitative estimation of physical vulnerability to landslides, Eng. Geol., 102, 251-253, 2008. 